\title{
Do sangue e sémen às cadeiras e bancadas \\ A nova dramaturgia britânica dos anos noventa e de agora
}

\author{
David Edgar
}

Quando tinha três anos e nove meses os meus pais levaramme pela primeira vez ao teatro. A peça era A bela e o monstro (Beauty and the Beast), de Nicholas Stuart Grey, e, à primeira entrada da assustadora criatura mascarada, gritei a plenos pulmões. 0 meu comportamento tornouse de tal maneira disruptivo que tive que ser retirado da sala. Como, por sorte, a minha tia era administradora desse teatro, escoltaram-me até aos bastidores para conhecer o Monstro no seu camarim, já sem a máscara, para lhe apertar a mão, para o ver colocar a máscara de novo, para lhe voltar a apertar a mão e para ser conduzido de volta ao auditório. Desta maneira tranquilizado, na sua entrada seguinte, gritei a plenos pulmões.

Desde então, tenho tido boas experiências no teatro, mas nenhuma como aquela. Um ano mais tarde voltei à mesma sala de espectáculos para ver, do mesmo autor, Tinder Box - uma peça cheia de bruxas sinistras e cães enormes. Mas dessa vez fui mais sensato. Apercebi-me de algo que precisaremos de nos lembrar várias vezes ao longo destas conferências sobre teatro e violência: é tudo a fingir.

Bem sei que não é assim tão simples. A fronteira entre o real e a ficção pode ser quebrada: alguma da violência no teatro contemporâneo não é a fingir. Mesmo que a violência seja simulada, há actividades delinquentes que Ihe estão associadas - incluindo o dizer palavrões e a nudez pública. E ainda que, tal como Sir Phillip Sidney, ninguém acredite que as portas de Tebas existam mesmo, parte da questão é suspeitar dessa descrença. Costumava ir ao teatro com alguém que, sabendo o que ia acontecer no Rei Lear, costumava fechar os olhos na cena da divisão do reino - ainda que o grande propósito da cegueira de Gloucester seja um convite para que, ao testemunharmos a sua simulação, nos desencorajemos de crueldades desse tipo na vida real.

Como é costume, quando fui convidado para estar nesta conferência, insisti que este não seria bem o meu tópico preferido. As minhas peças são conhecidas pela sua falta de sexo e de violência e, mesmo que recentemente tenha aumentado um pouco a violência, nunca vai muito para além da primeira escaramuça ou de um estrondo esquisito. Não obstante, e mais uma vez como de costume, fui convencido de que os meus pensamentos sobre este tópico seriam de interesse, ou de que - tal como o sermão de Canon Chasuble sobre o significado do "maná" no deserto em A importância de ser leal (The Importance of Being Earnest), de Oscar Wilde - os meus pensamentos sobre qualquer assunto poderiam ser adaptados a esta matéria. Tal como é hábito, à maneira de Fausto, aceitei o pacto, particularmente porque (neste caso) implicava um regresso à Bulgária.

Tudo o que posso apresentar é a maneira como o meu teatro - o teatro britânico - respondeu aos eventos dos últimos treze anos, já que o massacre de Srebrenica determinou o fim do optimismo precipitado de 1989, e marcou o momento em que nos começámos a afastar do sonho pan-europeu - naquilo que é descrito na Europa como o horrífico 11 de Setembro de 1989, tal como os americanos descrevem o 11 de Setembro de 2001. É uma história que começa com um teatro que se revolve em sangue e excreções, figurando aquilo que jamais tinha sido figurado, e que termina com um teatro que estremece no arrepio diegético da reportagem na terceira pessoa, incapaz de figurar seja o que for.

Há cinco anos atrás assisti ao congresso da Associação Internacional de Críticos de Teatro (AICT-IACT) em Novi Sad. Tal como a restante delegação britânica, fiquei surpreendido pela quantidade de tempo dispendido em discutir a esplêndida ou a perniciosa influência de um pequeno número de peças britânicas. Eu estava, como é óbvio, familiarizado com a popularidade do trabalho de Sarah Kane e de Mark Ravenhill no teatro europeu, e conheço agora os sinónimos de "comprar", "foder", "ruinas" e, obviamente, "psicose" no jargão de uma Europa alargada. E conhecia também a nova vaga do teatro britânico que emergiu em meados dos anos 90 - apelidado domesticamente como "bratpack", "in-yer-face-theatre",
David Edgar

é dramaturgo, britânico, autor de inúmeras peças para teatro, rádio, televisão, bem como de argumentos para cinema. Distinguido com vários prémios de teatro, aborda questões politicas nas suas peças e é autor de dois volumes de ensaios criticos: The Second Time as Farce (1988) e State of Play (1999). É actualmente 0 Presidente da Associação de Escritores da Grã-Bretanha. 
4.48 Psychose,

de Sarah Kane,

enc. Claude Regy, 2003

(Isabelle Huppert)

fot. Pascal Victor/MAXPPP.
Termos que em

português têm sido traduzidos por teatro de também ser traduzido por teatro de ruptura ou por "novo brutalismo". N.T.

2 Em Portugal a primeir vez em que o título

aparece traduzido, por Ana Bigotte Vieira, é num espectáculo dos Primeiros

Sintomas, Foder e ir às

compras, em 2006 "cutting edge theatre" ou "new brutalism"1 - e apelidado fora do Reino Unido como teatro de sangue e sémen ("blood and spunk theatre") ou "cool theatre" (aqui a partir de um interessante equívoco com o título da obra Teatro em ambiente de Guerra Fria (Theatre in a Cool Climate) [Ed. Vera Gottlieb e Colin Chambers, 1999]), ou por nada menos que Novo Drama Europeu (NDE). Contudo, até então, não me tinha apercebido da importância deste tipo de trabalho nas discussões que decorriam do lado continental do canal. Para alguns o NDE não era somente um repertório de literatura dramática, mas sim um local para o combate entre gerações no seio do teatro europeu. Esta leitura é a mesma que entende a cena alemã do pósguerra como dominada em particular pelos grandes encenadores auteurs, levando ao afastamento dos dramaturgos da sala de ensaios e dos palcos. Contudo, pelos anos noventa, o trabalho desta reputada mas envelhecida geração tornou-se intelectualmente árido, frio e sem emoção. Nomeado para a direç̧ão do Studio Baracke Space no Deutsches Theater de Berlim com vinte e poucos anos, Thomas Ostermeier viu em peças britânicas, tais como Ruinas (Blasted), de Sarah Kane, Comprar e foder ${ }^{2}$ (Shopping and Fucking), de Mark Ravenhill, e, mais tarde, em Gagarin Way, de Gregory Burke - e subsequentemente no trabalho de novos dramaturgos germânicos tais como Marius von Mayenburg - uma oportunidade para revitalizar o teatro europeu e para o pôr de novo em contacto com as gerações mais jovens.

Os críticos deste movimento acusarão o Novo Drama Europeu (NDE) de ser uma marca para um fenómeno essencialmente comercial. Argumentam que, apesar do todo o choque e espanto, o NDE é tão frio e árido como o teatro que aspira suplantar. Alquns apontam a diminuição de audiências do NDE britânico e dos seus sucedâneos, bem como o facto de Ostermeier, desde que assumiu a direcção do Schaubühne, se ter virado para a forma do teatro do pós-guerra regressando aos clássicos, como Casa de boneca e Hedda Gabler, de Ibsen.

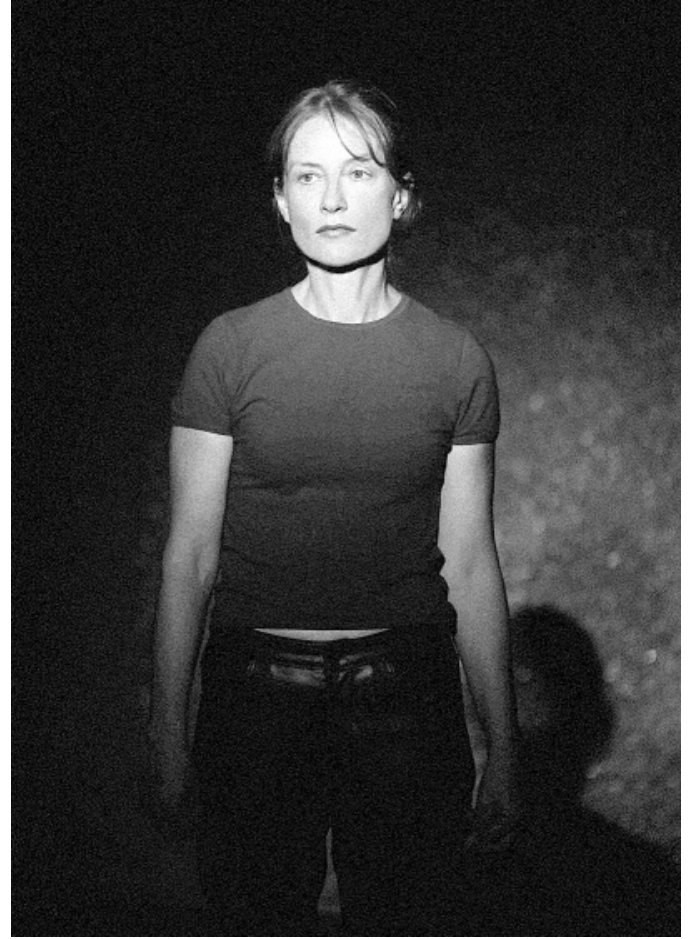

No Reino Unido, Ravenhill, Kane \&t Cia não fizeram parte de uma história da encenação, mas sim da escrita. Acredito que todos os grandes periodos de nova escrita no teatro britânico comungam de duas características: ocorreram no dealbar de grandes sentimentos nacionalistas; tinham um novo público desejoso de acompanhar as reais mudanças sociais e culturais. Também Shakespeare, vinte anos depois da derrota da Armada Invencivel, interroga o novo homem renascentista, liberto dos grilhões do feudalismo. Cerca de uma década depois da derrota da República puritana de Cromwell, Wycherley e Etherege desafiavam e, ao mesmo tempo, celebravam a atmosfera amoral e o ethos da Londres da Restauração. E o desafio colocado ao triunfante capitalismo industrial por Bernard Shaw, Granville Barker e, à sua maneira, por Wilde, aparece 20 ou 30 anos depois do zénite dos grandes feitos industriais e imperiais do Reino Unido. Também o momento teatral que teve inicio em 1956 tratava das consequências de uma sublevação, dirigindo-se a um público cujas vidas tinham sido alteradas por ela: a Segunda Guerra Mundial e as vastas mudanças que daí decorreram. Assim, dramaturgos como John Osborne, Arnold Wesker, até o Edward Bond dos primeiros anos, confrontavam-se nos seus textos com as consequências de uma perda de poder da classe trabalhadora, em alguns casos com entusiasmo, noutros com uma sensação de alarme. Para a geração que se Ihes seguiu, forjada na revolta juvenil dos anos sessenta, as questões eram muito mais agressivamente políticas. Tratavam dos limites da social-democracia e do Estado Providência e do debate entre as reformas liberais e a revolução socialista. No início dos anos oitenta, o estado de coisas muda mais uma vez quando jovens dramaturgos abordam as questões da diferença e da identidade que surgiram nos anos setenta e oitenta. Por seu lado, durante os anos noventa, os dramaturgos in-yer-face articularam as agonias frustradas de uma geração em que política era sinónimo de Margaret Thatcher, prazer de heroina, e sexo de SIDA. Tal como é amplamente conhecido, estes textos 


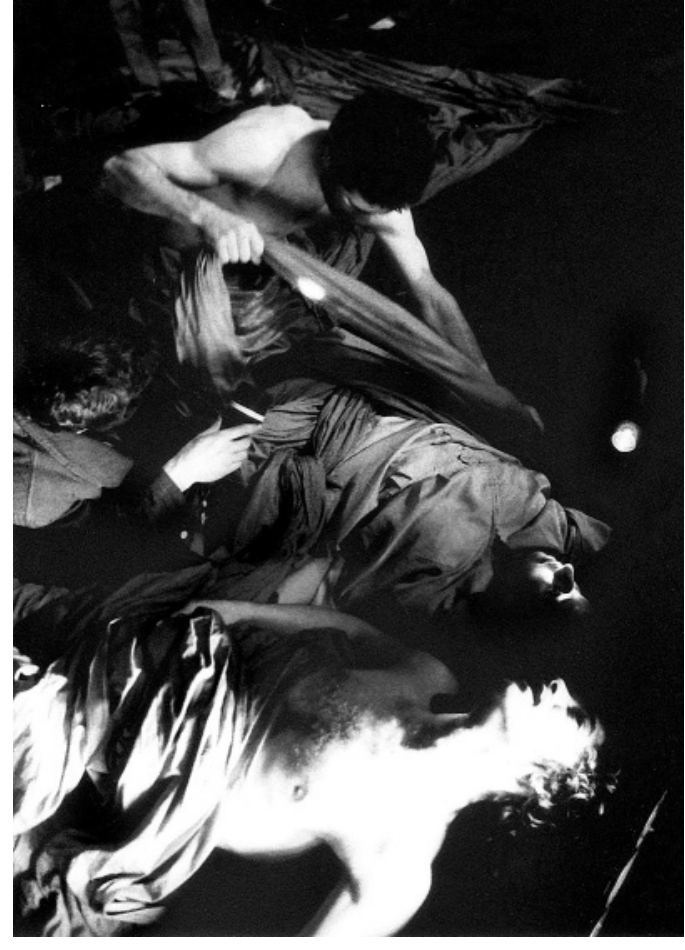

que eram sobre personagens jovens, com um estilo fleumático e brilhante, continham a representação de sexo explícito, uso de drogas e de violência. Muitas destas peças também partilhavam um tema que era, de facto, o tema dominante no teatro desse tempo. A peça dos meados dos anos noventa trata da masculinidade e da sua falência de modo tão evidente quanto as peças do início dos anos sessenta tratam de questões de classe e as dos anos setenta da falência da social-democracia. Dado que a masculinidade se cruza com temas económicos, culturais e sociais - muito particularmente com a violência e com o militarismo - trata-se de um tema político. Há uma certa crítica que argumenta que as pessoas que vivem na quietude confortável do norte da Europa não podem saber nada e que deverão ainda dizer menos sobre as guerras que estilhaçaram a Jugoslávia. Mas, certamente, o ressurgimento da barbárie no final do século XX veio juntar-se à toxicodependência e à SIDA e até ao crescente panorama sangrento contra o qual Kane, Ravenhill, Walsh, Burke, Pritchard e outros se insurgiam. E, finalmente, só porque Mark Ravenhill escreve sobre uma geração que não consegue vislumbrar nada para além da próxima terça-feira, ou para trás do passado fim-de-semana, isso não significa que ele a defenda. Entre outras coisas, Comprar e foder (Shopping and Fucking) é uma elegia pela perda das certezas políticas. Em Algumas polaróides explícitas (Some Explicit Polaroids), uma vitima de SIDA que se recusa a tomar a medicação que Ihe salvaria a vida, admite: "Eu quero o comunismo e o apartheid. Quero o dedo no gatilho nuclear. Quero a praga dos homossexuais. Quero saber onde estou". De maneira similar, Gagarin Way de Gregory Burke é sobre um grupo de protestatários - eloquentes mas ineficazes -, partidários da antiglobalização, que, de forma trapalhona e, mais tarde, desastrosa, raptam um empresário, o que conscientemente evoca o arrojado activismo da época precedente. Longe de celebrar a morte dos radicalismos políticos, parece-me que um dos grandes temas do teatro in-yer-face é o luto

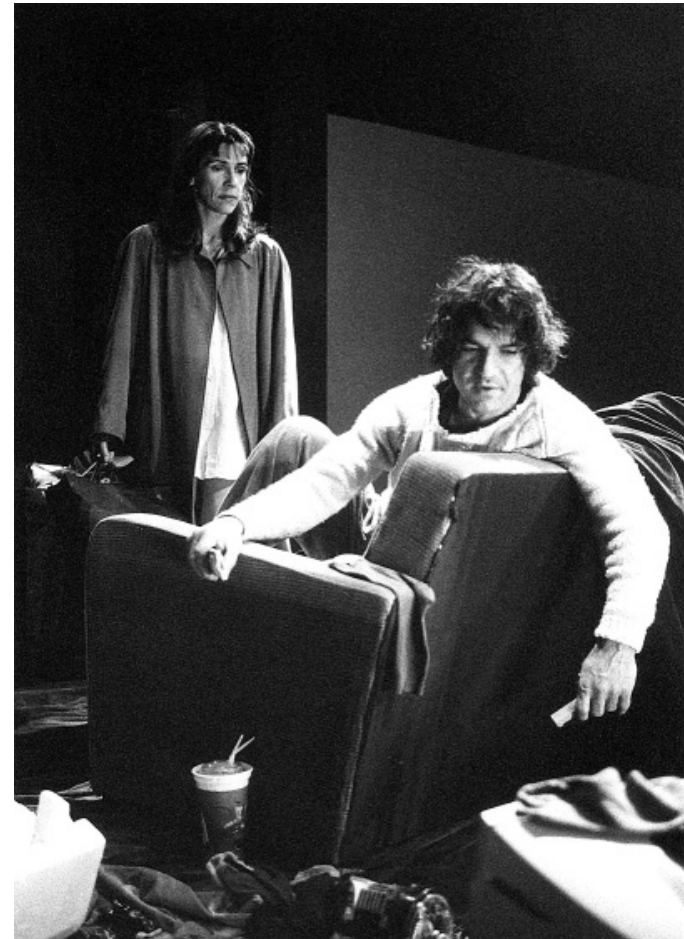

O amor de Fedro de Sarah Kane, enc. Jorge Silva Melo e Pedro Marques, Artistas Unidos, 2004 (> Teresa Sobral e Miguel Borges), fot. Jorge Gonçalves.

pela sua perda. Assim, seria surpreendente que, ao contrário dos seus antecedentes, um movimento com o dedo tão vincadamente colado ao "espírito do tempo" (Zeitgeist) pudesse durar para sempre. Não há dúvida que, após o suicídio de Sarah Kane, em Fevereiro de 1999, o teatro inyer-face sofreu um grande declínio.

Pelo virar do milénio, o domínio crescente de peças sobre jovens, que prosperam e vociferam em apartamentos no sul de Londres, deu azo à justificada inquietação de que um teatro que aspira a diagnosticar a crise da masculinidade era agora somente um sintoma disso mesmo; e de que uma dramaturgia, que aspira a lamentar o fim da política, se biodegradou em drama que mais não é do que a demonstração disso mesmo. E, previsivelmente, os abutres começaram logo a pairar: sempre que a nova dramaturgia se encontra temporariamente num pântano, críticos pós-modernos nas universidades e em todo o lado começam logo a proclamar a morte do teatro de texto. Nisto, encontram apoio junto da mais importante estrutura de apoio às artes, o Arts Council, que, na sua mais recente declaração política em relação ao teatro, abandona o incentivo à nova dramaturgia como uma prioridade em prol de "uma particular ênfase na prática experimental e interdisciplinar, no circo e nas artes de rua". Abram alas aos palhaços!

Contudo, penso que, mais uma vez, a morte da nova dramaturgia tem sido muito exagerada. É ainda muito cedo para olhar para a nova dramaturgia dos anos 2000 com a mesma confiança analítica com que olhamos para a do final dos anos cinquenta, a do início dos anos setenta e oitenta e a de meados dos anos noventa. Mas é claro que o 11 de Setembro deu à escrita um assunto novo. É também claro que da necessidade de lidar com o terrorismo e com a guerra, que foi montada contra ele, emergiu uma nova forma. Surpreendente e extraordinariamente, em claro contraste com o teatro in-yer-face, essa forma é essencialmente fria, distanciada e objectiva. Trata-se de um teatro baseado em factos ("fact-based theatre"). 


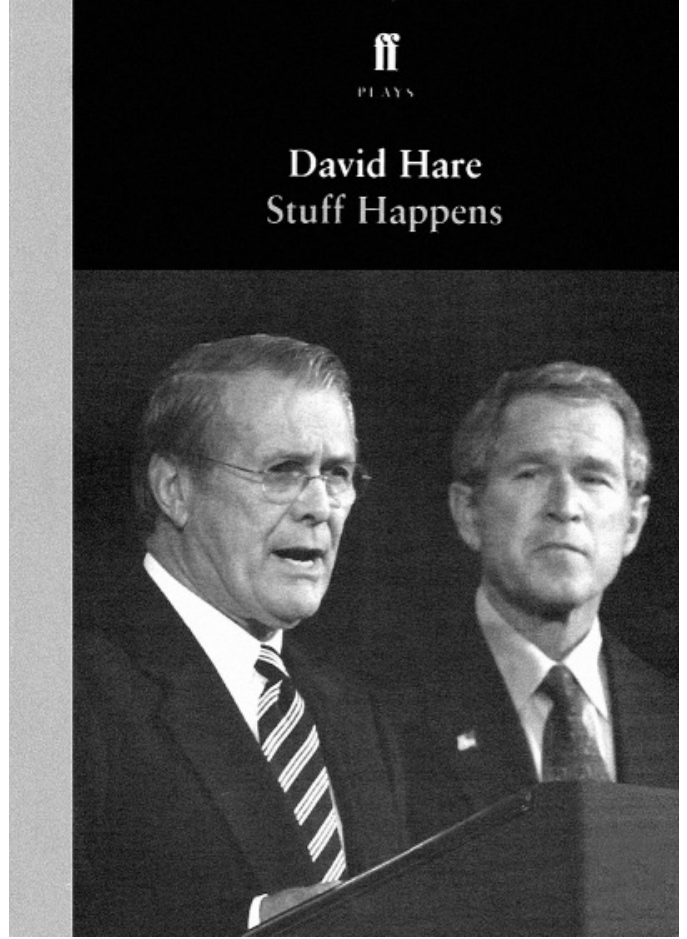

Praticamente todas as políticas britânicas do pós-11 de Setembro podem ser cartografadas e calibradas de acordo com uma rigorosa fidelidade em relação aos factos. De um lado está o teatro verbatim, tal como a série de dramatizações de julgamentos importantes no Tricycle Theatre, no norte de Londres, onde se incluiam interrogatórios sobre a morte de Stephen Lawrence, um jovem negro assassinado em Londres, e sobre o suicídio de David Kelly, um informante sobre a Guerra no Iraque. Aí estão espectáculos baseados em factos ("factual plays") tal como Guantanamo, de Victoria Brittain e Gillian Slovo, apresentado no Tricycle: é baseado em entrevistas publicadas de prisioneiros, dos seus parentes e advogados e nas declarações públicas de políticos. Entre outras peças baseadas em entrevistas inclui-se o Livro de cozinha árabeisraelita (Arab-Israeli Cookbook) de Robin Soans, um texto sobre o conflito no Médio Oriente feito a partir de entrevistas sobre comida, e, do mesmo autor, $\dot{A}$ conversa com terroristas (Talking to Terrorists), que era em grande medida precisamente o que o título deixa intuir. Ainda neste caminho, mas mais adiante, encontramos também São coisas que acontecem (Stuff Happens) de David Hare, que acoplava os acontecimentos desde o ataque de $11 \mathrm{de}$ Setembro até à invasão do Iraque, à maneira de um dramadocumentário televisivo tradicional. A muito celebrada peça de Gregory Burke sobre o regimento escocês e a sua participação no Iraque, Black Watch, apresentada no National Theatre of Scotland, era baseada em entrevistas com antigos soldados e continha aquilo que pareciam ser documentos e mensagens de correio electrónico genuinos. Ainda mais adiante estarão as peças satíricas de Alistair Beaton, que apresentam versões vagamente ficcionadas de figuras públicas tratando de forma satírica assuntos como a alteração e criação de factos oficiais e casamentos da realeza.

Entretanto, no extremo oposto a este teatro verbatim, alguns escritores têm criado peças em que os assuntos globais e domésticos suscitados pela "guerra ao terror" e
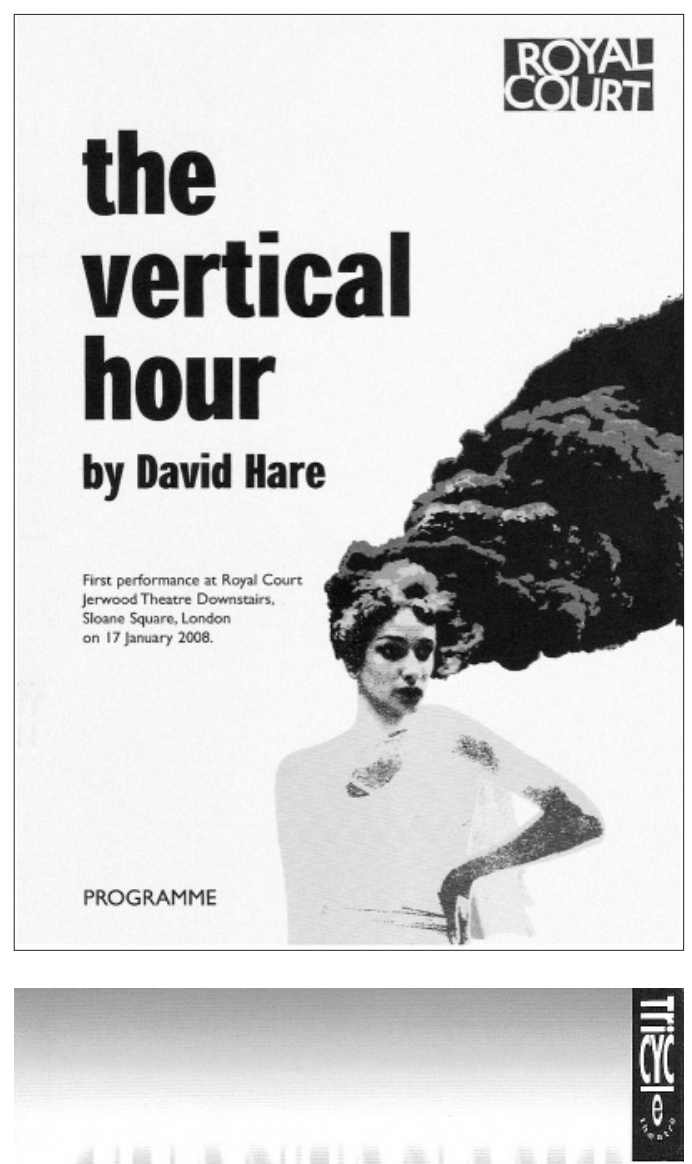

\section{GUANTANAMO 'HONOR BOUND TO DEFEND FREEDOM'}

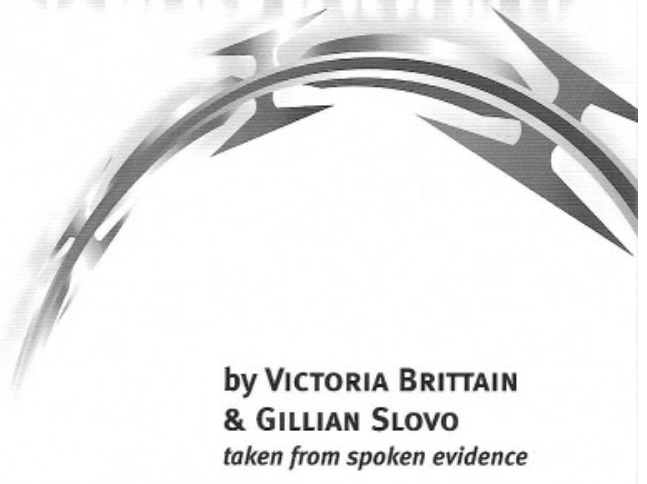

pela guerra do Iraque são confrontados com personagens ficcionais mas representativas, inseridas num cenário de eventos contemporâneos reais. Entre elas está a peça Dias com significado (Days of Significance), de Roy Williams, produzida recentemente pela Royal Shakespeare Company, sobre tropas britânicas no Iraque. Por último, existe a forma a que chamo "facção", em que uma série de fenómenos são condensados e ficcionados de maneira a se apresentar uma tese sobre as suas caracteristicas intrinsecas. Esta forma tem o mais elevado pedigree: 
inclui Alguém olhará por mim (Someone who'll Watch Over Me) de Frank McGuiness, uma versão facciosa do caso dos reféns em Beirute; Ausência de guerra (An Absence of War), de David Hare, sobre uma genérica desilusão eleitoral do Partido Trabalhista e as minhas próprias peças A forma da mesa (The Shape of the Table), 0 dilema do prisioneiro (The Prisoner's Dilemma) e Brincar com o fogo (Playing with Fire), que são, respectivamente, abstracções facciosas das revoluções anti-comunistas na Europa de Leste em 1989, dos processos internacionais pela paz de meados dos anos noventa e dos motins de 2001 em três cidades inglesas: Oldham, Burnley e Bradford.

Mas porquê os factos? Uma maneira de entender a questão é vê-la do ponto de vista histórico. Valerá a pena lembrar que já aqui tínhamos estado. Nos anos cinquenta e sessenta, a escola internacional do "teatro do facto" construía uma dramaturgia que assentava em documentos, em especial na transcrição de julgamentos. Contudo, a teoria por detrás destes trabalhos era precisamente não explicar o fenómeno que descreviam. A ideia de usar documentos como alternativa à invenção dramática era uma espécie de abdicação: correspondia a dizer que, depois das atrocidades de Auschwitz e Hiroshima, os velhos conceitos de causa e efeito já não se aplicavam. Tudo o que o dramaturgo poderia fazer seria apresentar os documentos, crus e sem adornos, e o leitor/espectador tiraria deles o que quisesse. Neste sentido, o "teatro do facto" é o outro lado da moeda do absurdismo dos anos 50 e 60 . Ambos visam representar um mundo que já não consegue ser analisado. Superficialmente, o teatro verbatim não surge nem como um descendente directo nem tão pouco como um filho bastardo do "teatro do facto". De entre todos, é David Hare quem não abandonou a sua missão de explicar. Mas interrogo-me se na antiteatralidade declarada dos tribunais do Trycicle ou do minimalismo da reportagem de Robin Soans (a questão que se coloca muitas vezes antes de muitas peças verbatim é "serão bancos ou bancadas desta vez?"), se não haverá um elemento que, se não for de abdicação, será um desejo de apresentar ao público um vasto conjunto de pontos que este terá de preencher e juntar? A questão com a "facção" é que se trata de uma maneira de apresentar uma tese não estorvada por factos específicos. Umas das vantagens do teatro verbatim é que se apresentam factos específicos não estorvados por uma tese.

Assim, o teatro verbatim tornou-se progressivamente metatextual, extraído não só "de" entrevistas, como também "sobre" entrevistas. Eli, aparece (Come Out Eli), de Aleky Blythe's - uma peça sobre um cerco em Londres na qual os actores escutavam, através de auriculares, as entrevistas originais dos intervenientes - é simultaneamente sobre o processo e sobre o produto final (começa e termina com a reprodução das negociações entre Blythe e uma testemunha chave que aceitava apenas dar o seu testemunho em troca de sexo). Black Watch tem cenas que representam as entrevistas nas quais a peça se baseia, com o "Escritor" como personagem, e nas quais os soldados entrevistados manifestam a sua decepção pelo facto de a vistosa entrevistadora feminina (real e nomeada) não fazer parte do processo das entrevistas. Do mesmo modo, A conversa com terroristas (Talking to Terrorists) de Robin Soans parecia ser mais sobre o contraste entre as vidas domésticas e sobre os maneirismos dos entrevistados do que sobre a enormidade do terrorismo (nesse sentido, podia muito bem ser $\dot{A}$ conversa com ambientalistas (Talking to Environmentalists) ou Ȧ conversa com traficantes de droga (Talking to Drug-Dealers). Progressivamente, os tribunais do Trycicle têm sido tanto sobre o contraste entre a frieza da forma inquisitiva e sobre o calor dos acontecimentos que procuram explicar, como sobre a reportagem. Enquanto que a mais recente peça de julgamento apresentada no Trycicle - Instado a prestar contas (Called do Acount) - editava da maneira do costume um falso julgamento de Tony Blair por crimes de guerra; e Tomar conta da criança (Taking Care of Baby) de Dennis Kelly era uma versão para palco do 
de Sarah Kane,

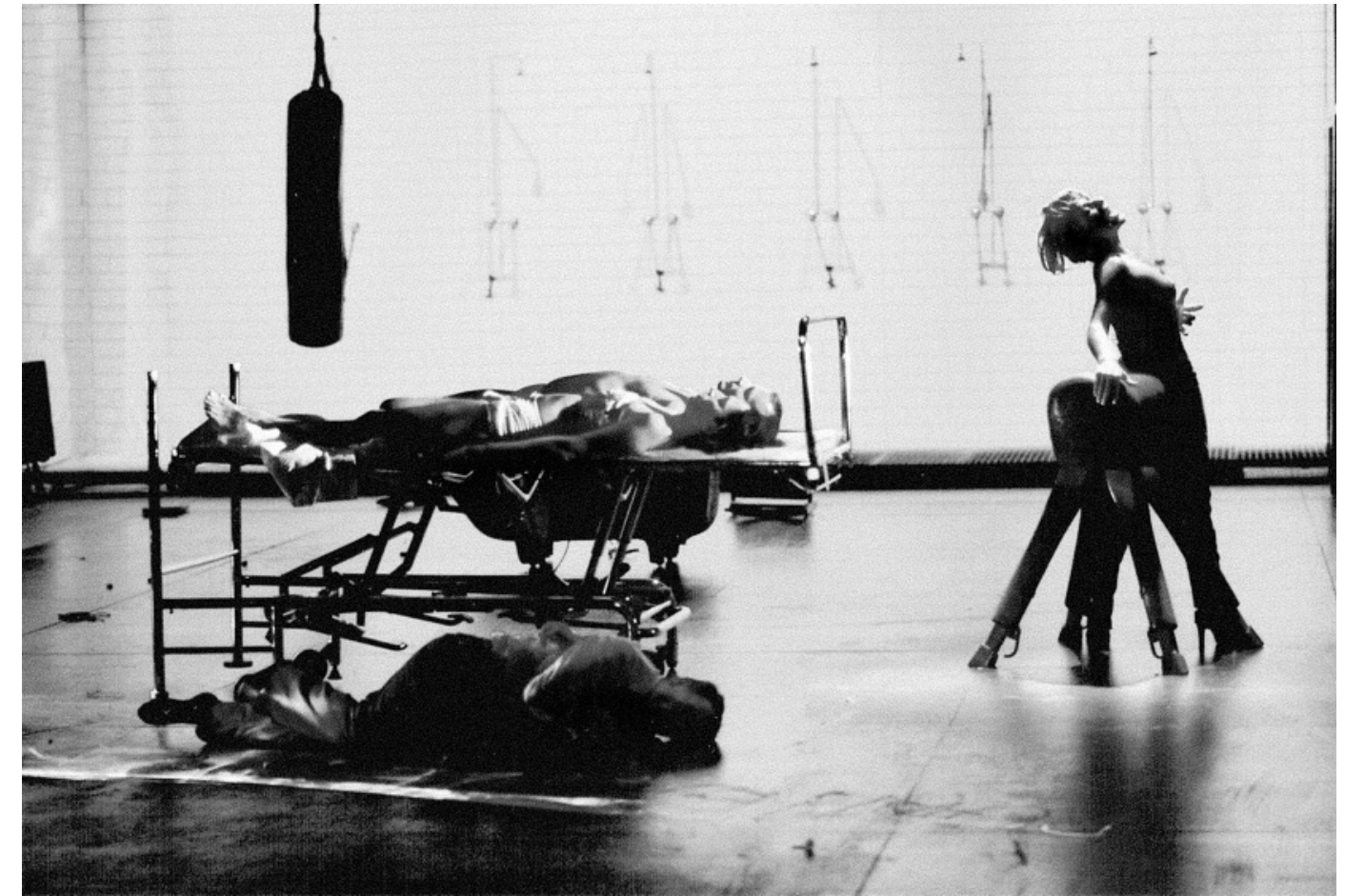

documentário-paródia televisivo, criado a partir de um trabalho ficcional sobre uma mulher que é erradamente presa por matar o seu filho, em que se mantém durante quase metade do espectáculo a ilusão de se tratar de um verdadeiro verbatim baseado em entrevistas reais e sobre um caso verídico.

Assim, o teatro aborda hoje importantes temas actuais a uma dupla distância. Abrindo caminho a processos narrativos (entrevistas ou julgamentos) coloca aspas nos eventos frequentemente sangrentos que descreve. Chamar à dramaturgia britânica de meados dos anos 90 "cool theatre" foi o resultado de um erro de tradução. Chamar ao teatro desta década "cool theatre" é uma descrição crítica precisa e, no que diz respeito à maior parte desta década, continua a ser cada vez mais frio.

Mas algo mais está a acontecer. À medida que o teatro verbatim se enreda nas suas próprias citações, o tradicional drama mimético pode estar de volta. Argumentei mais atrás que a Nova Dramaturgia Britânica se apresentou sempre de forma mais vibrante nos períodos em que teve um novo público, a quem se dirigir, e novos temas, com que se preocupar, no espaço partilhado e seguro da ficção dramática. Um exemplo recente é a maneira como uma multidão de jovens asiáticas em Birmingham vai assistir a espectáculos com peças escritas por jovens asiáticas, sobre as suas preocupações acerca de cultura, sexualidade, familia e religião. Mais recentemente, um grupo de dramaturgos mais veteranos tem usado a ficção teatral para abordar os dilemas que têm fraccionado a esquerda liberal e progressista; como estamos confortáveis (ou não) por marcharmos lado a lado com pessoas que são demonizadas domesticamente e invadidas nos seus paises, mas cujas opiniões sobre um vasto leque de assuntos desde os direitos das mulheres e dos homossexuais até à liberdade de expressão - são opostos aos nossos. Este é, em parte, o caso do texto muito tradicional, dividido em cinco partes, A hora vertical (The Vertical Hour), de David Hare, um sucesso em Nova lorque no ano passado, reposto

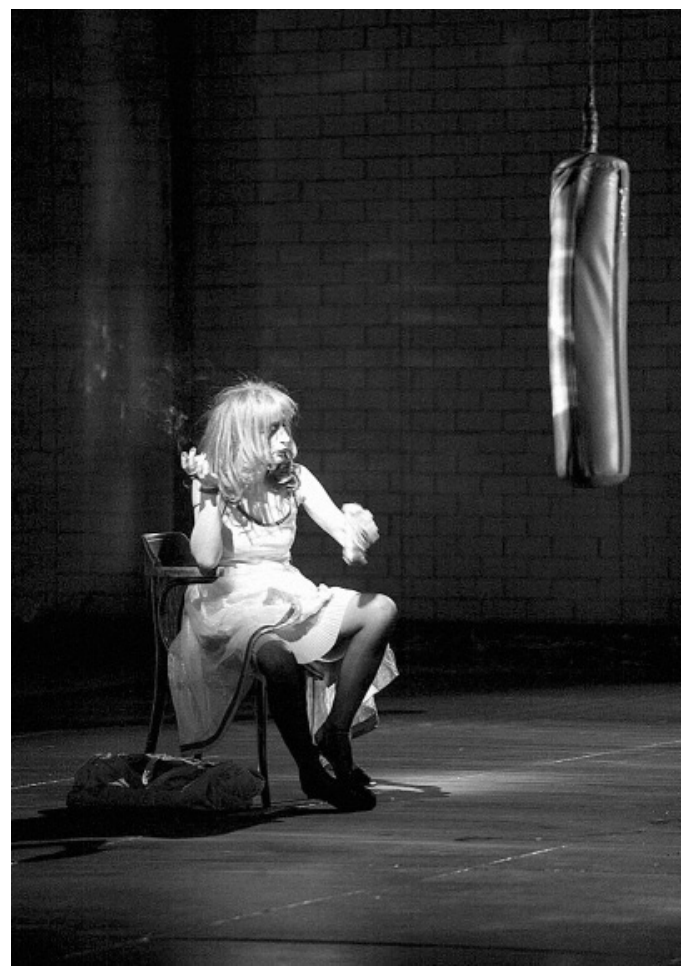

recentemente no Royal Court, em Londres. É também este o tema de dois textos recentemente levados à cena em Londres. Um é uma peça-mosaico sobre os exames que na Inglaterra e noutros paises se fazem a pessoas que requerem a cidadania. A questão principal prende-se com uma professora de inglês que se defronta com um aluno muçulmano que a acusa de ser discriminatória. Esta é uma peça que usa técnicas de montagem do teatro agitprop para levantar questões para as quais o autor não tem respostas convincentes. 0 outro texto é uma série de pequenas peças de 20 minutos, representadas por toda a cidade de Londres. Muitas começavam no reconhecível 


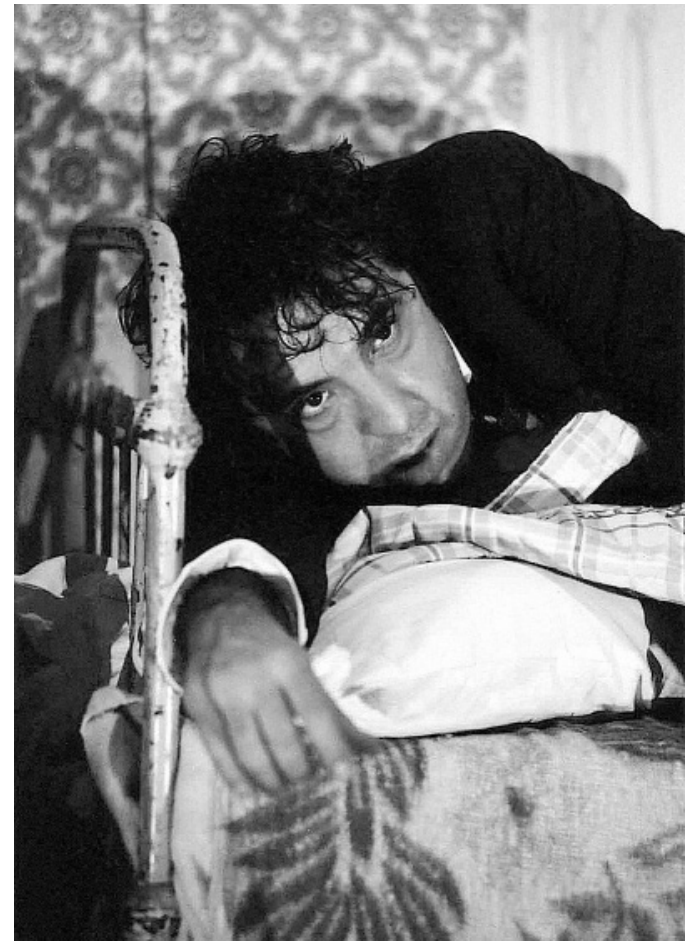

mundo do consumismo liberal da classe média, um mundo desafiado e perturbado quer pelos agressores quer pelas vítimas da guerra contra o terror: no último espectáculo, um grupo de "artistas-monitores", que entravam num pais devastado pela guerra, são confrontados por uma mulher cega, com a boca cheia de sangue e que morre em espasmos à frente do público. De certa maneira, estas peças confrontam a dramaturgia do virar do milénio com o drama dos anos 90, perturbando a frieza tranquila do drama de tribunal com as imagens sangrentas do teatro in-yer-face. Intitulada Atira/Obtém tesouro/Repete (Shoot/Get Treasure/Repeat), a peça-mosaico foi escrita dia-a-dia durante o Festival de Edimburgo do ano passado por Mark Ravenhill. A peça sobre o teste de cidadania,

intitulada Testando o eco (Testing the Echo) foi escrita por mim.

Há cinco anos atrás, em Novi Sad, argumentei que a nova dramaturgia teria que ter um papel preponderante, de provocação e de oposição na cultura britânica. Há a ideia generalizada de que, em particular após o 11 de Setembro, as várias formas de teatro baseado em factos não abordaram as grandes questões do novo milénio com a convicção com que gerações anteriores abordaram classe e género. Claramente, as peças que aqui referi - escritas por homens com cerca de quarenta anos - não vão providenciar um vocabulário para o teatro britânico pósverbatim. Pode até bem ser que o seu tema nem seja o grande tema do teatro que há-de vir. Mas julgo que estará entre eles.

Quero concluir pelo principio. Este ano o teatro britânico celebra $040^{\circ}$ aniversário da abolição da censura teatral, instituída em 1727, durante a qual, sob os auspicios de um agente representante de Sua Majestade, os dramaturgos foram proibidos de mostrar dois homens numa cama, mencionar doenças venéreas, criticar a familia real, insultar potências estrangeiras aliadas, ou representar Deus. Durante os vinte anos seguintes à sua abolição, pudemos acreditar que a luta pela liberdade de expressão

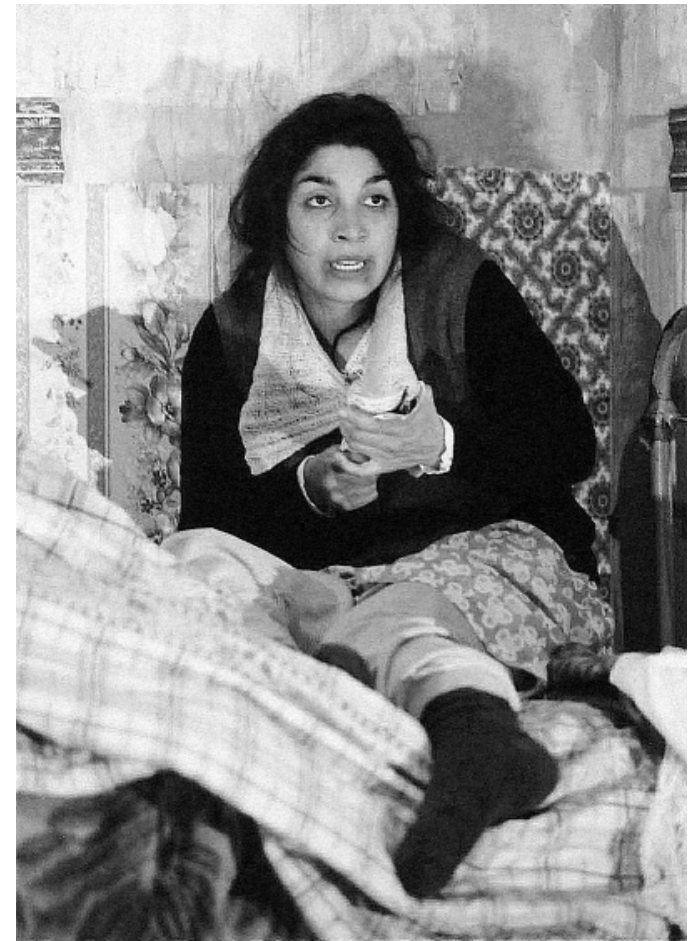

Acamarrados, Artistas Unidos, 2008 (< António Simão; $>$ Carla Galvão) fot. Jorge Andrade. fora ganha e que os constrangimentos ao livre discurso se poderiam resumir à proverbial declaração de Oliver Wendell Holmes, que em 1919 proibia "gritar 'fogo!' num teatro lotado provocando o pânico".

Hoje, os medos sobre a influência de imagens sexualmente explícitas e violentas, a mercantilização de todas as formas de cultura, a preocupação crescente com as vitimas de crimes e com o emergente movimento contra a crítica à religião, estão entre os diversos factores que alargam a malha desta rede. Agora, na proibição de Holmes já não está somente a questão de prevenir a saída precipitada de uma multidão em fuga: hoje, gritar "fogo!" pode ser censurado por perturbar os familiares das vitimas de outros incêndios, violar os direitos dos bombeiros, ofender as religiões para as quais o fogo é um elemento sagrado, e glorificar, minimizar ou encorajar o fogo-posto. Todas estas possibilidades advêm da ideia de que, fundamentalmente, lá no fundo, gritar "fogo!" é atear um incêndio.

0 teatro é por natureza extremo. Por nos permitir imaginar o que será ver o mundo através de outros olhos (incluindo através dos olhos dos violentos e dos assassinos), a representação artística desenvolve capacidades sem as quais não poderíamos viver juntos em sociedade. 0 livre discurso não é primordialmente uma questão que se prenda com os direitos do falante, mas com os direitos do ouvinte. Nesse sentido, todos temos o direito não só de indignar e aterrorizar, mas também de nos sentirmos indignados e aterrorizados. Afinal de contas, o que acontece no início de Henrique V? Um homem grita 'fogo!' num teatro apinhado.

Tradução de Rui Pina Coelho 